\title{
Photosynthetic Responses of Swiss Chard, Kale, and Spinach Cultivars to Irradiance and Carbon Dioxide Concentration
}

\author{
John Erwin ${ }^{1,3}$ and Esther Gesick ${ }^{2}$ \\ Department of Horticultural Science, University of Minnesota, 305 Alderman \\ Hall, 1970 Folwell Avenue, St. Paul, MN 55108
}

Additional index words. Brassica, Beta, Spinacea, light saturation point, $\mathrm{CO}_{2}$ saturation point, respiration

\begin{abstract}
The impact of irradiance $\left(0-1200 \mu \mathrm{mol} \cdot \mathrm{m}^{-2} \cdot \mathrm{s}^{-1}\right)$ and carbon dioxide concentration $\left(\mathrm{CO}_{2} ; 50-1200 \mathrm{ppm}\right)$ on kale (Brassica oleracea and $B$. napus pabularia; three cultivars), Swiss chard (chard, Beta vulgaris; four cultivars), and spinach (Spinacea oleracea; three cultivars) photosynthetic rate $\left(P_{n}\right.$; per area basis) was determined to facilitate maximizing yield in controlled environment production. Spinach, chard, and kale maximum $P_{\mathrm{n}}$ were $23.8,20.3$, and $18.2 \mu \mathrm{mol} \mathrm{CO}_{2} \cdot \mathrm{m}^{-2} \cdot \mathrm{s}^{-1}$ fixed, respectively, across varieties $\left(400 \mathrm{ppm} \mathrm{CO}_{2}\right)$. Spinach and kale had the highest and lowest light compensation points [LCPs (73 and $13 \mu \mathrm{mol} \cdot \mathrm{m}^{-2} \cdot \mathrm{s}^{-1}$, respectively)] across varieties. The light saturation points (LSPs) for chard and kale were similar at $884-978 \mu \mathrm{mol} \cdot \mathrm{m}^{-2} \cdot \mathrm{s}^{-1}$, but for spinach, the LSP was higher at $1238 \mu \mathrm{mol} \cdot \mathrm{m}^{-2} \cdot \mathrm{s}^{-1}$. Dark respiration was lowest on kale and highest on spinach $\left(-0.83\right.$ and $-5.00 \mu \mathrm{mol} \mathrm{CO} \mathrm{CO}_{2} \cdot \mathrm{m}^{-2} \cdot \mathrm{s}^{-1}$, respectively). The spinach $\mathrm{CO}_{2}$ compensation point (CCP) was lower $(56 \mathrm{ppm})$ than the chard or kale $\mathrm{CCP}$ (64-65 ppm). Among varieties, 'Red Russian' kale $P_{\mathrm{n}}$ saturated at the lowest $\mathrm{CO}_{2}$ concentration $(858 \mathrm{ppm})$, and 'Bright Lights' chard saturated at the highest (1266 ppm; $\left.300 \mu \mathrm{mol} \cdot \mathrm{m}^{-2} \cdot \mathrm{s}^{-1}\right)$. Spinach $P_{\mathrm{n}}$ was more responsive to increasing irradiance than to $\mathrm{CO}_{2}$. Kale $P_{n}$ was more responsive to increasing $\mathrm{CO}_{2}$ than to irradiance, and chard $P_{n}$ was equally responsive to increasing $\mathrm{CO}_{2}$ or irradiance. Implications and limitations of this work when "upscaling" to whole-plant responses are discussed.
\end{abstract}

Leafy green vegetable options are increasing as communities become more ethnically or racially diverse or both, as the health and nutritional benefits of greens consumption are reported (Bertoia et al., 2015; $\mathrm{Hu}$ and Rimm, 2015), and as interest in year-round locally produced foods increases (Feldmann and Hamm, 2015). Three increasingly popular leafy vegetables are kale (Brassica oleracea and B. napus pabularia), spinach (Spinacea oleracea), and Swiss chard (chard, Beta vulgaris).

Kale, spinach, and chard leaves are harvested and sold on a fresh-weight basis. The ability of plants to increase fresh weight, or mass, is associated with photosynthesis where plant mass generally increases as

\footnotetext{
Received for publication 20 Jan. 2017. Accepted for publication 5 Apr. 2017.

The authors acknowledge and appreciate the financial support of the Minnesota Agriculture Experiment Station, USDA-ARS Floriculture and Nursery Research Initiative (FNRI), National Institute of Food and Agriculture (NIFA), and members of the University of Minnesota through the Floriculture Research Alliance including Altman Plants, Inc., Rocket Farms, Inc., Smith Gardens, Inc., and Green Circle Growers, Inc.

${ }^{1}$ Professor.

${ }^{2}$ Research Fellow.

${ }^{3}$ Corresponding author. E-mail: erwin001@umn. edu.
}

photosynthesis increases (Björkman, 1981; Chagvardieff et al., 1994; Dorais, 2003). The primary inputs into the photosynthetic process are light (irradiance), $\mathrm{CO}_{2}$, and water (Björkman, 1981). Therefore, maximizing photosynthesis in leafy greens to maximize yield would require that irradiance, $\mathrm{CO}_{2}$, or water not be limited (Fu et al., 2017; Gaudreau et al., 1994; Gent, 2016).

In northern climates, year-round leafy green production requires protected cultivation during the late fall, winter, and early spring when temperatures drop below freezing. Irradiance and $\mathrm{CO}_{2}$ in protected cultivation often vary, intentionally and unintentionally, depending on covering type, plant spacing, degree of ventilation, whether air is circulated, and whether supplemental lighting or $\mathrm{CO}_{2}$ are supplied (Kretchen and Howlett, 1970). Little work has been conducted on the effects of irradiance and $\mathrm{CO}_{2}$ on the $P_{\mathrm{n}}$ of leafy greens other than lettuce (Lactuca sativa; Dorais, 2003; Fu et al., 2017; Gaudreau et al., 1994) and recent work by Gent (2016) on spinach. An understanding of how irradiance and $\mathrm{CO}_{2}$ impact the $P_{\mathrm{n}}$ of such greens would facilitate maximizing the $P_{\mathrm{n}}$ to maximize yield in protected cultivation. The objective of the research presented here was to determine the $P_{\mathrm{n}}$ responses of spinach, kale, and chard to irradiance and $\mathrm{CO}_{2}$ and to inform producers of the advantages or disadvantages of reduced or increased irradiance or $\mathrm{CO}_{2}$ on yield. We also desired to determine whether leafy green varieties differed in the $P_{\mathrm{n}}$ responses to irradiance and $\mathrm{CO}_{2}$ and whether some varieties were more suited to supplemental, or reduced, irradiance and $\mathrm{CO}_{2}$ levels.

We acknowledge that translating instantaneous $P_{\mathrm{n}}$ measurements on a per-unit-area basis to whole-plant photosynthesis has limitations (see Discussion). Yet, an initial comparative study exploring the variation in the instantaneous $P_{\mathrm{n}}$ on a per-unit-area basis is valuable in that it provides some insight into the degree of variation among species and varieties. These data also provide some guidance on irradiance and $\mathrm{CO}_{2}$ levels that maximize the $P_{\mathrm{n}}$ on the uppermost leaves, especially when plants are young and interior leaf shading is limited.

\section{Materials and Methods}

Chard, ['Rhubarb', 'Fordhook Giant', 'Bright Yellow', and 'Bright Lights' (red)], kale ['Toscano', 'Winterbor', and 'Red Russian' (B. napus pabularia)], and spinach ('Melody', 'Harmony', and 'Bloomsdale LS') seeds were sown in 10.5 -cm-diameter plastic pots (5 seeds/pot) in premoistened LC-8 soilless growing media (Sun Gro Horticulture, Bellevue, WA) and placed in a greenhouse $\left(24 \pm 2{ }^{\circ} \mathrm{C}\right.$ day and $16 \pm 2{ }^{\circ} \mathrm{C}$ night temperatures; St. Paul, MN). Kale and chard seeds were obtained from Johnny's Selected Seeds (Winslow, ME), and spinach seeds were obtained from W. Atlee Burpee \& Co. (Warminster, PA). Seeds germinated in 4-7 d.

Greenhouse daylight (0800-1400 HR) was supplemented with $75 \mu \mathrm{mol} \cdot \mathrm{m}^{-2} \cdot \mathrm{s}^{-1}$ highpressure sodium lighting when daylight (at plant level) was below $200 \mu \mathrm{mol} \cdot \mathrm{m}^{-2} \cdot \mathrm{s}^{-1}$. After $7 \mathrm{~d}$, the three most uniform (similar size) seedlings were left to grow, whereas the others were removed. As kale and chard flower after they unfold a specific leaf number, after a cool temperature exposure, or both, daylength was extended with 75 $\mu \mathrm{mol} \cdot \mathrm{m}^{-2} \cdot \mathrm{s}^{-1}$ from $1600-2200 \mathrm{HR}$ as flowering was not a concern [16 h photoperiod; mean daily light integral $(\mathrm{DLI})=12.4$ $\mathrm{mol} \cdot \mathrm{m}^{-2} \cdot \mathrm{d}^{-1}$ ] to simulate a typical production environment to maximize yield (J. Erwin, personal observation). In contrast, as long days can promote flowering on spinach early in development, spinach seedlings were grown under short days $(8 \mathrm{~h}$ photoperiod; opaque cloth pulled over plants from 1400 $0800 \mathrm{HR}$ daily; mean DLI $=10.7 \mathrm{~mol} \cdot \mathrm{m}^{-2} \cdot \mathrm{d}^{-1}$ ) to inhibit flowering. After $30 \mathrm{~d}$, plants were transplanted into 7.6-1 plastic pots. Throughout, plants were watered as needed with irrigation water containing $250 \mathrm{ppm} \mathrm{N}$ from $15 \mathrm{~N}-0 \mathrm{P}-15 \mathrm{~K}$ fertilizer (Peter's Dark Weather Feed; The Scotts Co., Marysville, OH). All plants were watered at the same time to ensure similar media nutritional status (confirmed with soil tests) among species and varieties.

Photosynthetic rate determination. After kale plants unfolded seven true leaves $\left(>45^{\circ}\right.$ angle from the stem), chard plants unfolded four leaves, and spinach plants unfolded eight 
leaves ( $\approx 4$ weeks across species), the impact of irradiance and $\mathrm{CO}_{2}$ on instantaneous $P_{\mathrm{n}}$ on a per-unit-leaf-area basis was determined on the second leaf below the uppermost fully expanded unfolded leaf on five plants of each species and variety. The $P_{\mathrm{n}}$ was measured using a LI-COR LI6400XT portable photosynthesis meter (LI-COR, Inc., Lincoln, NE) using a cuvette $\left(6 \mathrm{~cm}^{2}\right)$ with a built-in variable LED light source. The $P_{\mathrm{n}}$ at $0,100,200$, $400,600,800,1000$, and $1200 \mu \mathrm{mol} \cdot \mathrm{m}^{-2} \cdot \mathrm{s}^{-1}$ irradiance was determined. The $P_{\mathrm{n}}$ at 50, 200, 400, 600, 800, 1000, and 1200 ppm $\mathrm{CO}_{2}$ was also determined. The $P_{\mathrm{n}}$ was recorded $5 \mathrm{~min}$ after a change in irradiance or $\mathrm{CO}_{2}$ after the $P_{\mathrm{n}}$ had stabilized. Throughout, cuvette temperature was maintained at $24{ }^{\circ} \mathrm{C}$, and the atmospheric flow rate was $400 \mu \mathrm{L} \cdot \mathrm{min}^{-1}$. Cuvette $\mathrm{CO}_{2}$ was 400 ppm (outdoor ambient) when determining the $P_{\mathrm{n}}$ responses to irradiance, and irradiance was $300 \mu \mathrm{mol} \cdot \mathrm{m}^{-2} \cdot \mathrm{s}^{-1}$ (typical irradiance in a northern U.S. greenhouse during the winter; personal observation) when measuring the $P_{\mathrm{n}}$ responses to $\mathrm{CO}_{2}$.

Photosynthetic parameter determination. The $P_{\mathrm{n}}$ data from each leaf of each species and variety at varying irradiance or $\mathrm{CO}_{2}$ were fit to the nonlinear Mitscherlich and the nonrectangular hyperbola functions as both are widely used to estimate the $P_{\mathrm{n}}$ responses to irradiance and $\mathrm{CO}_{2}$ (Aleric and Kirkman, 2005; Goudrian, 1979; Johnson et al., 2010; Laitat and Boussard, 1995; Marino et al., 2010; Peek et al., 2002; Potvin et al., 1990). The Mitscherlich equations (Eqs. [1] and [2]) fit data best here and provided realistic nonlinear parameter values (Table 1; personal observation). More complex biochemical models estimating the leaf $P_{\mathrm{n}}$ [such as used by Farquhar et al. (1980)] were not used, as we quantified the $P_{\mathrm{n}}$ responses to $\mathrm{CO}_{2}$ at irradiance levels typical in northern greenhouses here and not saturating levels typically used with biochemical models.

$$
P_{\mathrm{n}}(\mathrm{I})=P_{\max }\left(1-\mathrm{e}^{-\mathrm{k}\left(\mathrm{I}-\mathrm{I}_{0}\right)}\right)
$$

Eq. [1] shows $P_{\mathrm{n}}$ responses $\left[P_{\mathrm{n}}(\mathrm{I})\right]$ to irradiance $(\mathrm{I}) . P_{\mathrm{n}}$ responses to increasing irradiance were asymptotic here; " $P_{\max }$ " in Eq. [1] estimates the asymptote. LSP was the irradiance at $95 \%$ of $P_{\max }$. "I $\mathrm{I}_{0}$ " was the LCP (irradiance when estimated $P_{\mathrm{n}}=0 \mu \mathrm{mol} \cdot \mathrm{m}^{-2} \cdot \mathrm{s}^{-1}$ $\mathrm{CO}_{2}$ fixed), and " $k$ " was a constant that represented the ratio of the quantum yield $(q)$ to the $P_{\mathrm{n}}$ at the LCP (Marino et al., 2010). $R_{\mathrm{d}}$ (dark respiration) was calculated as the estimated $P_{\mathrm{n}}(\mathrm{I})$ when irradiance was $0 \mu \mathrm{mol} \cdot \mathrm{m}^{-2} \cdot \mathrm{s}^{-1}$.

$$
P_{\mathrm{n}}(\mathrm{C})=P_{\max }\left(1-\mathrm{e}^{-\mathrm{k}\left(\mathrm{C}-\mathrm{C}_{0}\right)}\right)
$$

Eq. [2] shows $P_{\mathrm{n}}$ responses $\left[\left(\mathrm{P}_{\mathrm{n}}(\mathrm{C})\right]\right.$ to $\mathrm{CO}_{2} . P_{\mathrm{n}}$ responses to increasing $\mathrm{CO}_{2}$ were asymptotic; " $P_{\max }$ " in Eq. [2] estimates the asymptote. " $\mathrm{C}_{0}$ " is the estimated $\mathrm{CCP}\left(\mathrm{CO}_{2}\right.$ when $P_{\mathrm{n}}=0 \mu \mathrm{mol} \cdot \mathrm{m}^{-2} \cdot \mathrm{s}^{-1} \mathrm{CO}_{2}$ fixed), and " $k$ " is a constant. The $\mathrm{CO}_{2}$ concentration at $95 \%$ of $P_{\max }$ approximated the $\mathrm{CO}_{2}$ saturation point (CSP; $\mathrm{CO}_{2}$ when $P_{\mathrm{n}}$ was saturated).

Experimental design and data analysis. Analysis of variance (ANOVA) was conducted on photosynthetic parameters derived from Eqs. [1] and [2] fit to $P_{\mathrm{n}}$ data from each leaf on each plant as dependent variables. The experiment was analyzed as a two-stage nested design using Type I sum of squares, which allows the use of Tukey's honestly significant difference (HSD) for mean separation with species as the first factor and cultivar the second. Estimated $k$ values, $r^{2}$, and mean square errors (MSEs) derived from the ANOVA are shown in Table 1. Tukey's HSD $(\alpha<0.05)$ was employed for mean separation except in Table 4 where least significant difference (LSD; $\alpha<0.05$ ) was employed as Tukey's HSD cannot be employed with a repeated measures test. A Tukey's test conducted when sphericity is violated (often the case with collected repeated measures tests) will have a vastly inflated Type I error rate; SPSS (see below) presumably does not include Tukey's test as an option under repeated measures analysis to prevent this error. The best test to compare multiple comparisons in a repeated measures design is Bonferroni's; for our data, Bonferroni's gave the same results as LSD. Aside from this case, Tukey's HSD was used when possible as it is more statistically rigorous than LSD. Throughout, the SPSS statistical software package (IBM SPSS Statistics, Version 23; IBM Corp., Armonk, NY) was used for statistical analysis.

\section{Results}

Photosynthetic responses to irradiance. $P_{\max }$ (identified by providing saturating irradiance levels at 400 ppm $\mathrm{CO}_{2}$ ) differed among species, varieties within a species, and across all varieties (Table 2). Spinach had the highest $P_{\max }$ at $23.8 \mu \mathrm{mol} \mathrm{CO} \mathrm{CO}_{2} \cdot \mathrm{m}^{-2} \cdot \mathrm{s}^{-1}$ fixed, whereas for kale it was $20.3 \mu \mathrm{mol} \mathrm{CO} 2 \cdot \mathrm{m}^{-2} \cdot \mathrm{s}^{-1}$ fixed and for chard it was $18.2 \mu \mathrm{mol} \mathrm{CO} 2 \cdot \mathrm{m}^{-2} \cdot \mathrm{s}^{-1}$ fixed (across varieties; Fig. 1; Table 2). Among kale varieties, 'Red Russian' and 'Toscano' had a higher $P_{\max }\left(21.0-22.3 \mu \mathrm{mol} \mathrm{CO} \cdot \mathrm{m}^{-2} \cdot \mathrm{s}^{-1}\right)$ than 'Winterbor' (17.4 $\mu \mathrm{mol} \quad \mathrm{CO}_{2} \cdot \mathrm{m}^{-2} \cdot \mathrm{s}^{-1}$; Table 2). Among spinach varieties, 'Melody' had a higher $P_{\max }\left(26.6 \mu \mathrm{mol} \mathrm{CO} \mathrm{CO}_{2} \cdot \mathrm{m}^{-2} \cdot \mathrm{s}^{-1}\right)$ than 'Harmony' or 'Bloomsdale LS' (22.3$22.4 \mu \mathrm{mol} \mathrm{CO}{ }_{2} \cdot \mathrm{m}^{-2} \cdot \mathrm{s}^{-1}$; Table 2). Among chard varieties, 'Fordhook Giant' had a higher $P_{\max }$ $\left(21.9 \mu \mathrm{mol} \mathrm{CO} \mathrm{CO}_{2} \cdot \mathrm{m}^{-2} \cdot \mathrm{s}^{-1}\right)$ than 'Bright Lights' or 'Yellow' (16.3-16.6 $\mu \mathrm{mol} \quad \mathrm{CO}_{2} \cdot \mathrm{m}^{-2} \cdot \mathrm{s}^{-1}$; Table 2). Across all species and varieties, 'Melody' spinach had the highest $P_{\max }$, and 'Yellow' and 'Bright Lights' chard had the lowest $P_{\max }$ (Table 2).

Spinach had the highest LCP (73 $\left.\mu \mathrm{mol} \cdot \mathrm{m}^{-2} \cdot \mathrm{s}^{-1}\right)$, the LCP of chard was 25 $\mu \mathrm{mol} \cdot \mathrm{m}^{-2} \cdot \mathrm{s}^{-1}$, and kale had the lowest LCP at $13 \mu \mathrm{mol} \cdot \mathrm{m}^{-2} \cdot \mathrm{s}^{-1}$ (Table 2). Kale and spinach variety LCP did not differ, but chard variety LCP differed from 16 (Bright Lights) to 41 umol $\cdot \mathrm{m}^{-2} \cdot \mathrm{s}^{-1}$ (Rhubarb; Table 2). Chard and kale LSP $\left(884-978 \mu \mathrm{mol} \cdot \mathrm{m}^{-2} \cdot \mathrm{s}^{-1}\right)$ did not differ, but spinach LSP was higher (1238 $\mu \mathrm{mol} \cdot \mathrm{m}^{-2} \cdot \mathrm{s}^{-1}$; Table 2). LSP did not differ among varieties within any species studied here (Table 2).

Photosynthetic responses to $\mathrm{CO}_{2}$ concentra tion. $P_{\max }$ (identified by providing saturating $\mathrm{CO}_{2}$ concentrations at $300 \mu \mathrm{mol} \cdot \mathrm{m}^{-2} \cdot \mathrm{s}^{-1}$ ) differed among some species, among varieties within some species, and across all varieties (Table 3). Chard and kale $P_{\max }$ did not differ (17.2-17.6 $\mu \mathrm{mol} \mathrm{CO} \mathrm{CO}_{2} \cdot \mathrm{m}^{-2} \cdot \mathrm{s}^{-1}$ fixed), but spinach $P_{\max }$ was higher at $19.8 \mu \mathrm{mol} \mathrm{CO} \mathrm{CO}_{2} \cdot \mathrm{m}^{-2} \cdot \mathrm{s}^{-1}$ fixed (across varieties; Fig. 1; Table 3). $P_{\max }$ did not differ among spinach varieties. Among kale varieties, 'Winterbor' had a lower $P_{\max }$ than 'Red Russian' (Table 3). Chard $P_{\max }$ varied from $16.6 \mu \mathrm{mol} \mathrm{CO} \mathrm{CO}_{2} \cdot \mathrm{m}^{-2} \cdot \mathrm{s}^{-1}$ for 'Rhubarb' to $19.2 \mu \mathrm{mol} \mathrm{CO} \cdot \mathrm{m}^{-2} \cdot \mathrm{s}^{-1}$ for 'Bright Lights' (Table 3). Across varieties,

Table 1. Statistics associated with goodness of fit of raw data to the nonlinear Mitscherlich function used to describe responses of kale (Brassica oleracea and $B$. napus pabularia; three cultivars), spinach (Spinacea oleracea; three cultivars), and Swiss chard (Beta vulgaris; four cultivars) to irradiance and carbon dioxide

\begin{tabular}{|c|c|c|c|c|c|c|}
\hline \multirow[b]{2}{*}{ Plant type } & \multicolumn{3}{|c|}{ Irradiance } & \multicolumn{3}{|c|}{ Carbon dioxide concn } \\
\hline & $k$ & $r^{2}$ & MSE & $k$ & $r^{2}$ & MSE \\
\hline Kale & 0.0031 & 0.996 & 0.157 & 0.0033 & 0.998 & 0.122 \\
\hline 'Red Russian' & 0.0030 & 0.999 & 0.059 & 0.0038 & 0.998 & 0.149 \\
\hline 'Winterbor' & 0.0034 & 0.991 & 0.234 & 0.0028 & 0.999 & 0.048 \\
\hline 'Toscano' & 0.0030 & 0.998 & 0.180 & 0.0032 & 0.998 & 0.168 \\
\hline Spinach & 0.0027 & 0.999 & 0.038 & 0.0032 & 0.999 & 0.068 \\
\hline 'Melody' & 0.0026 & 0.999 & 0.058 & 0.0034 & 0.999 & 0.056 \\
\hline 'Harmony' & 0.0028 & 1.000 & 0.027 & 0.0032 & 0.999 & 0.064 \\
\hline 'Bloomsdale LS' & 0.0026 & 0.999 & 0.030 & 0.0030 & 0.999 & 0.083 \\
\hline Swiss chard & 0.0036 & 0.998 & 0.099 & 0.0030 & 0.998 & 0.177 \\
\hline 'Yellow' & 0.0040 & 0.999 & 0.051 & 0.0030 & 0.993 & 0.524 \\
\hline 'Rhubarb' & 0.0034 & 0.997 & 0.165 & 0.0035 & 1.000 & 0.016 \\
\hline 'Fordhook Giant' & 0.0030 & 0.999 & 0.088 & 0.0030 & 1.000 & 0.023 \\
\hline 'Bright Lights' & 0.0040 & 0.998 & 0.093 & 0.0026 & 0.999 & 0.112 \\
\hline
\end{tabular}
concentration. The $r^{2}$, mean square error (MSE), and " $k$ " values (Mitscherlich function) fit to data are shown. 
Table 2. Variation in predicted maximum photosynthetic rate $\left(P_{\max }\right)$, the light compensation point (irradiance at $\left.P_{\mathrm{n}}=0\right)$, the light saturation point (irradiance at $95 \%$ of $\left.P_{\max }\right)$, predicted dark respiration rate $\left(\mathrm{CO}_{2}\right.$ evolution in dark at $\left.24^{\circ} \mathrm{C}\right)$, and quantum efficiency among three varieties of kale (Brassica oleracea and $\mathrm{B}$. napus pabularia), three varieties of spinach (Spinacea oleracea), and four varieties of Swiss chard (Beta vulgaris) as determined using a fitted Mitscherlich model for each plant of each species and variety. Capital letters denote mean separation $\left[\right.$ Tukey's $\left.\mathrm{HSD}_{(0.05)}\right]$ across species, and small letters denote mean separation across varieties.

\begin{tabular}{|c|c|c|c|c|c|}
\hline Plant species/variety & $\begin{array}{c}\text { Maximum photosynthetic } \\
\text { compensation rate }\left(\mu \mathrm{mol} \mathrm{CO} \mathrm{CO}_{2} \cdot \mathrm{m}^{-2} \cdot \mathrm{s}^{-1}\right)\end{array}$ & $\begin{array}{l}\text { Light saturation point } \\
\left(\mu \mathrm{mol} \mathrm{CO}_{2} \cdot \mathrm{m}^{-2} \cdot \mathrm{s}^{-1}\right)\end{array}$ & $\begin{array}{c}\text { Light respiration } \\
\text { point }\left(\mu \mathrm{mol} \mathrm{CO} 2 \cdot \mathrm{m}^{-2} \cdot \mathrm{s}^{-1}\right)\end{array}$ & $\begin{array}{c}\text { Dark efficiency } \\
\text { rate }\left(\mu \mathrm{mol} \mathrm{CO} \mathrm{CO}_{2} \cdot \mathrm{m}^{-2} \cdot \mathrm{s}^{-1}\right)\end{array}$ & Quantum \\
\hline 'Red Russian' & $22.3 \pm 0.5 \mathrm{~d}$ & $16 \pm 2 a b$ & $1,015 \pm 2$ & $-1.12 \pm 0.12 \mathrm{c}$ & $0.07 \pm 0.002$ \\
\hline 'Toscano' & $21.0 \pm 1.1 \mathrm{bcd}$ & $15 \pm 2 \mathrm{ab}$ & $1,014 \pm 2$ & $-0.97 \pm 0.11 \mathrm{c}$ & $0.06 \pm 0.004$ \\
\hline Spinach & $23.8 \mathrm{C}$ & $73 \mathrm{C}$ & $1,238 \mathrm{~B}$ & $-5.00 \mathrm{~A}$ & $0.08 \mathrm{~B}$ \\
\hline 'Melody' & $26.6 \pm 0.7 \mathrm{e}$ & $68 \pm 3 \mathrm{e}$ & $1,266 \pm 123$ & $-5.05 \pm 0.44 \mathrm{a}$ & $0.08 \pm 0.007$ \\
\hline 'Harmony' & $22.4 \pm 1.2 \mathrm{~d}$ & $79 \pm 3 \mathrm{e}$ & $1,177 \pm 102$ & $-5.51 \pm 0.43 \mathrm{a}$ & $0.08 \pm 0.006$ \\
\hline 'Bright Lights' & $16.6 \pm 0.8 \mathrm{a}$ & $16 \pm 2 \mathrm{ab}$ & $784 \pm 64$ & $-10.6 \pm 0.13 \mathrm{c}$ & $0.07 \pm 0.003$ \\
\hline 'Fordhook Giant' & $21.9 \pm 0.7 \mathrm{~cd}$ & $22 \pm 2 b$ & $1,021 \pm 17$ & $-1.49 \pm 0.11 b c$ & $0.07 \pm 0.002$ \\
\hline 'Rhubarb' & $18.0 \pm 0.8 \mathrm{abc}$ & $41 \pm 4 \mathrm{c}$ & $939 \pm 65$ & $-2.60 \pm 0.20 b$ & $0.07 \pm 0.004$ \\
\hline 'Yellow' & $16.3 \pm 0.9 \mathrm{a}$ & $21 \pm 4 b$ & $790 \pm 65$ & $-1.43 \pm 0.31 \mathrm{bc}$ & $0.07 \pm 0.004$ \\
\hline \multicolumn{6}{|l|}{ Analysis of Variance } \\
\hline Species & $* * * \mathrm{z}$ & $* * *$ & $* * *$ & $* * *$ & * \\
\hline Variety & $* * *$ & $* * *$ & NS & $* * *$ & NS \\
\hline
\end{tabular}

HSD $=$ honestly significant difference; NS $=$ nonsignificant.

${ }^{\mathrm{z}}$ Denotes significance at the $\alpha<0.05(*),<0.01,\left({ }^{* *}\right),<0.001(* * *)$ levels.

'Winterbor' kale had the lowest $P_{\max }$ (14.7 $\left.\mu \mathrm{mol} \mathrm{CO} \cdot \mathrm{m}^{-2} \cdot \mathrm{s}^{-1}\right)$, and 'Red Russian' and 'Toscano' kale had the highest $\mathrm{P}_{\max }(17.8$ and $19.0 \mu \mathrm{mol} \quad \mathrm{CO}_{2} \cdot \mathrm{m}^{-2} \cdot \mathrm{s}^{-1}$, respectively; Table 3).

Spinach CCP was lower (56 ppm) than chard or kale CCPs (64-65 ppm) across varieties (Table 3). CCP did not differ among spinach or chard varieties, but differed among kale varieties where 'Red Russian' had the lowest CCP (59 ppm) and 'Winterbor' the highest (72 ppm; Table 3). CSP did not vary among species or among varieties within a species, but differed when all varieties were compared; 'Red Russian' kale had the lowest CSP (858 ppm), and 'Bright Lights' chard had the highest CSP (1266 ppm; Table 3).

Dark respiration. Calculated $R_{\mathrm{d}}\left(24{ }^{\circ} \mathrm{C}\right)$ differed among species. Kale $R_{\mathrm{d}}$ was the lowest $\left(-0.83 \mu \mathrm{mol} \mathrm{CO} \mathrm{CO}_{2} \cdot \mathrm{m}^{-2} \cdot \mathrm{s}^{-1}\right)$, chard $R_{\mathrm{d}}$ was $-1.64 \mu \mathrm{mol} \mathrm{CO} \cdot \mathrm{m}^{-2} \cdot \mathrm{s}^{-1}$, and spinach $R_{\mathrm{d}}$ was the highest $\left(-5.00 \mu \mathrm{mol} \quad \mathrm{CO}_{2} \cdot \mathrm{m}^{-2} \cdot \mathrm{s}^{-1}\right.$; across varieties; Table 2 ). $R_{\mathrm{d}}$ did not differ among kale and spinach varieties, but differed among chard varieties where 'Rhubarb' and 'Bright Lights' chard $R_{\mathrm{d}}$ was -2.60 and $-10.06 \mu \mathrm{mol} \mathrm{CO} 2 \cdot \mathrm{m}^{-2} \cdot \mathrm{s}^{-1}$, respectively (Table 2).

\section{Discussion}

Limitations of generalizing instantaneous $P_{n}$ data on a per-unit-area basis to wholeplant $P_{n}$. Data here provide a framework for determining irradiance and $\mathrm{CO}_{2}$ impacts on kale, spinach, and chard $P_{\mathrm{n}}$ to facilitate production in controlled environment facilities to maximize yield. $P_{\mathrm{n}}$ is often associated with dry weight gain, fresh weight gain, and yield in vegetables (Heuvelink and Dorais, 2003). There are limitations when extrapolating changes in instantaneous $P_{\mathrm{n}}$ measurements on a per-unit-area basis to whole-plant $P_{\mathrm{n}}$ and conclusions drawn from that data. For instance, instantaneous $P_{\mathrm{n}}$ responses can differ from whole-plant responses when a) multiple inputs are changed at once, b) after plants acclimate to altered irradiance, $\mathrm{CO}_{2}$, or both, and c) when leaf aging and whole-plant leaf area/shading are taken into account.

One environmental parameter (irradiance or $\mathrm{CO}_{2}$ ) was changed while the other was held constant in our research here. Increasing irradiance and $\mathrm{CO}_{2}$ simultaneously may produce different conclusions, likely increasing LSP, CSP, or both more than reported here. For instance, Chagvardieff et al. (1994) observed increasing $\mathrm{CO}_{2}$ and irradiance simultaneously increased lettuce dry weight $69 \%$ more than dry weight gains observed from increasing $\mathrm{CO}_{2}$ and irradiance separately, i.e., there was a synergy between these factors. Also, other environmental parameters can interact with irradiance, $\mathrm{CO}_{2}$, or both to impact $P_{\mathrm{n}}$. Changes in humidity (Kaiser et al., 2015) or temperature (Dahal et al., 2012) can result in markedly different responses in $P_{\mathrm{n}}$ to irradiance, $\mathrm{CO}_{2}$, or both. Nonenvironmental cultural factors can also impact $P_{\mathrm{n}}$ and assumptions made here. For instance, high irradiance promotion of $P_{\mathrm{n}}$ was most obvious when lettuce was grown under low nitrogen levels only $\left(7 \mathrm{mmol} \cdot \mathrm{L}^{-1} ; \mathrm{Fu}\right.$ et al., 2017).

Photosynthetic rate can acclimate to altered irradiance or $\mathrm{CO}_{2}$ over time (Björkman, 1981; Lambers et al., 2008; Pons, 2012). Therefore, caution should be exercised when extrapolating instantaneous $P_{\mathrm{n}}$ responses to whole-plant $P_{\mathrm{n}}$ over time. $P_{\mathrm{n}}$ at high irradiance or $\mathrm{CO}_{2}$ may be overpredicted, and $P_{\mathrm{n}}$ at low irradiance or $\mathrm{CO}_{2}$ may be underpredicted over time (Bunce and Ziska, 2000). The basis for $P_{\mathrm{n}}$ acclimation to altered irradiance or $\mathrm{CO}_{2}$ is not clear. Acclimation of $P_{\mathrm{n}}$ to high irradiance or $\mathrm{CO}_{2}$ was more correlated with soluble saccharides than with day to day variation in $\mathrm{CO}_{2}$ or irradiance alone (Bunce and Sicher, 2003). In contrast, variation among Arabidopsis varieties in $P_{\mathrm{n}}$ over time to irradiance was associated with differences in Rubsico activation and stomatal conductance $\left(g_{S}\right)$ (Kaiser et al., 2016).

Also, the transferability of our conclusions to whole-plant responses is associated with the size (or age) of a plant and leaf area. High irradiance can result in reduced leaf life or smaller leaf area which can result in an overestimating whole-plant $P_{\mathrm{n}}$ if reduced leaf area, more rapid leaf senescence, or both is not taken into account (Austin, 1989). Also, although $P_{\mathrm{n}}$ on the uppermost leaf may be saturated, whole-plant $P_{\mathrm{n}}$ is likely not saturated as lower leaves are shaded in a canopy as a plant grows and unfolds leaves. Such shading results in $P_{\mathrm{n}}$ rates lower than the $P_{\max }$ on lower leaves even when irradiance on the uppermost leaves is at the LSP. Irradiance in a canopy decreases exponentially from the top to the bottom of a plant following the general equation $\mathrm{I}=\mathrm{I}_{\mathrm{o}} \mathrm{e}^{-\mathrm{kL}}[I=$ irradiance below the canopy; $\mathrm{I}_{\mathrm{o}}=$ irradiance at the top of the canopy; $k=$ the extinction coefficient (generally $>0.5$ for nonvertically oriented leaves); and $\mathrm{L}=$ leaf area index (Lambers et al., 2008)]. Therefore, increasing irradiance at the top of the plant above the LSP will likely increase whole-plant $P_{\mathrm{n}}$ if the leaf area index is high.

Although these limitations when translating instantaneous $P_{\mathrm{n}}$ data to crop responses exist, we believe $P_{\mathrm{n}}$ responses are still informative. Specifically, instantaneous $P_{\mathrm{n}}$ data on a per-unit-area basis provide insight into variation in responses among species and varieties that is of value and provide some insight into which species or varieties may be more responsive to increases in irradiance or $\mathrm{CO}_{2}$ concentration.

Responses to irradiance. Kale and chard $P_{\mathrm{n}}$ saturated at lower $\left(600-800 \mu \mathrm{mol} \cdot \mathrm{m}^{-2} \cdot \mathrm{s}^{-1}\right)$ irradiance levels than spinach $(1000-1200$ $\mu \mathrm{mol} \cdot \mathrm{m}^{-2} \cdot \mathrm{s}^{-1} ; 400 \mathrm{ppm} \mathrm{CO}_{2}$; Fig. 1; Table 2). $\mathrm{P}_{\max }$ reported here are consistent with previous data on spinach (Boese and Huner, 1990; Yamori et al., 2005) and kale 

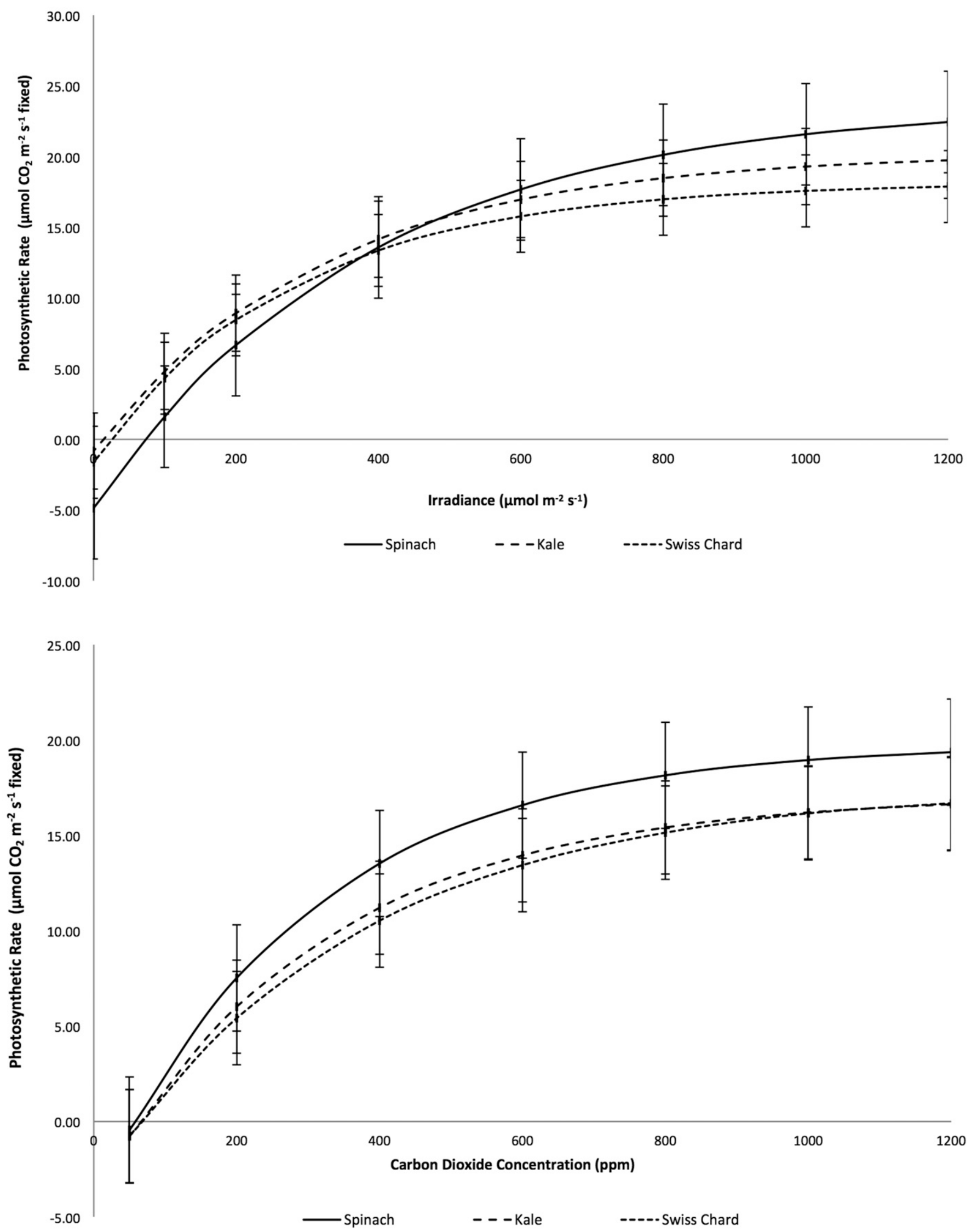

Fig. 1. Effect of increasing irradiance (A) or carbon dioxide $\left(\mathrm{CO}_{2}\right)$ concentration (B) on spinach (Spinacea oleracea), kale (Brassica oleracea and B. napus pabularia), and Swiss chard (Beta vulgaris) photosynthetic rate across cultivars. Bars represent the \pm mean square error as identified through analysis of variance $(\alpha<0.05)$. 
Table 3. Variation in the predicted maximum photosynthetic rate $\left(P_{\max } ; \mu \mathrm{mol} \mathrm{CO} \mathrm{CO}^{-2} \cdot \mathrm{s}^{-1}\right)$, the $\mathrm{CCP}\left(\mathrm{CO}_{2}\right.$ concentration when $\left.P_{\mathrm{n}}=0\right)$, and the CSP (the $\mathrm{CO} 2$ concentration at $95 \% P_{\max }$ ) among three cultivars of kale (Brassica oleracea and B. napus pabularia), three cultivars of spinach (Spinacea oleracea), and four cultivars of Swiss chard (Beta vulgaris) as determined using fitted Mitscherlich functions fit to each cultivar and pooled under each species. Capital letters denote mean separation [Tukey's $\mathrm{HSD}_{(0.05)}$ ] across species, and small letters denote mean separation across cultivars.

\begin{tabular}{|c|c|c|c|}
\hline Plant species/cultivar & $P_{\max }\left(\mu \mathrm{mol} \mathrm{CO} \mathrm{CO}_{2} \cdot \mathrm{m}^{-2} \cdot \mathrm{s}^{-1}\right)$ & $\mathrm{CCP}(\mathrm{ppm})$ & CSP (ppm) \\
\hline Kale & $17.2 \mathrm{~A}$ & $65.0 \mathrm{~B}$ & 1,014 \\
\hline 'Toscano' & $19.0+0.3 \mathrm{cde}$ & $64.4+2.1 \mathrm{bcd}$ & $1,013+51 \mathrm{ab}$ \\
\hline 'Winterbor' & $14.7+0.5 \mathrm{a}$ & $71.8+3.1 \mathrm{~d}$ & $1,170+101 a b$ \\
\hline 'Melody' & $19.8+0.2 \mathrm{de}$ & $54.8+0.8 \mathrm{a}$ & $954+61 a b$ \\
\hline 'Harmony' & $19.6+0.3 \mathrm{de}$ & $55.6+1.0 \mathrm{ab}$ & $1,004+51 \mathrm{ab}$ \\
\hline 'Bloomsdale LS' & $20.0+0.4 \mathrm{e}$ & $58.0+1.1 \mathrm{abc}$ & $1,057+11 \mathrm{ab}$ \\
\hline 'Fordhook Giant' & $17.5+0.7 \mathrm{bcd}$ & $64.1+3.1 \mathrm{abcd}$ & $1,113+125 a b$ \\
\hline 'Rhubarb' & $16.6+0.9 \mathrm{ab}$ & $63.0+1.9 \mathrm{abcd}$ & $939+73 a b$ \\
\hline 'Yellow' & $16.9+0.6 \mathrm{abc}$ & $62.8+0.7 \mathrm{abcd}$ & $1,061+74 \mathrm{ab}$ \\
\hline \multicolumn{4}{|l|}{ Analysis of Variance } \\
\hline Species & $* * * \mathrm{z}$ & $* * *$ & NS \\
\hline Cultivar & $* * *$ & ** & * \\
\hline
\end{tabular}

$P_{\max }=$ maximum photosynthetic rate; $\mathrm{CCP}=\mathrm{CO}_{2}$ compensation point; $\mathrm{CSP}=\mathrm{CO}_{2}$ saturation point; $\mathrm{HSD}=$ honestly significant difference; $\mathrm{NS}=$ nonsignificant.

${ }^{\mathrm{z}}$ Denotes significance at the $\alpha<0.05(*),<0.01,(* *),<0.001(* * *)$ levels.

[Brassica; Dahal et al. (2012) (napus) and Ruhil et al. (2015)] at slightly lower $\mathrm{CO}_{2}$ concentrations than used here. Given irradiance in northern climates in greenhouses rarely exceeds LSPs reported here (personal observation), supplemental lighting (up to the LSPs, at a minimum) would increase $P_{\mathrm{n}}$ and presumably yield. Supplemental lighting in northern greenhouse vegetable production facilities is commonplace as growers observe increased yield when providing supplemental light. In greenhouse lettuce production, daylight is often supplemented with $50-100$ $\mu \mathrm{mol} \cdot \mathrm{m}^{-2} \cdot \mathrm{s}^{-1} \quad\left(\mathrm{DLI}=12-13 \mathrm{~mol} \cdot \mathrm{m}^{-2} \cdot \mathrm{d}^{-1}\right)$ during the winter to realize $140 \%$ to $270 \%$ increases in yield compared with plants with no supplemental lighting in Canada (Gaudreau et al., 1994). Similarly, Brassicaceae microgreen (seedling) fresh weight and nutritional value increased when irradiance was increased from 0 to $320-440 \mu \mathrm{mol} \cdot \mathrm{m}^{-2} \cdot \mathrm{s}^{-1}$, but not when irradiance was further increased from 440 to $545 \mu \mathrm{mol} \cdot \mathrm{m}^{-2} \cdot \mathrm{s}^{-1}$ (Samuoliene et al., 2013). In contrast, Colonna et al. (2016) showed that the impact of irradiance on the nutritional value of 10 leafy vegetables varied with species.

Daily light integral can be more associated with yield than with irradiance as it represents the cumulative light delivered over $24 \mathrm{~h}$. For instance, spinach dry weight as a ratio of fresh weight increased as normalized daily light integral (DLI/leaf area index) increased from 3 to $27 \mathrm{~mol} \cdot \mathrm{m}^{-2} \cdot \mathrm{d}^{-1}$ (Gent, 2016). However, it is important to note that a high correlation between DLI and plant dry weight will occur only if irradiance is below the LSP; irradiance levels above the LSP would not result in an increase in $P_{\mathrm{n}}$.

Based on the instantaneous $P_{\mathrm{n}}$ data here, kale and chard may be better suited for production in naturally low irradiance locations or facilities than spinach as their LSP were lower than that of spinach (Table 2). Also, as spinach had a higher LCP (60-75 $\left.\mu \mathrm{mol} \cdot \mathrm{m}^{-2} \cdot \mathrm{s}^{-1}\right)$ than kale $\left(10-15 \mu \mathrm{mol} \cdot \mathrm{m}^{-2} \cdot \mathrm{s}^{-1}\right)$, kale may be grown under lower irradiance conditions than spinach and still have a net increase in mass. Again, we emphasize that these assumptions are based on instantaneous data, and plants may acclimate to lower irradiance levels over time.

Table 4 shows predicted percent changes in $P_{\mathrm{n}}$ when irradiance was increased from 300 to $350 \mu \mathrm{mol} \cdot \mathrm{m}^{-2} \cdot \mathrm{s}^{-1}$ on kale, chard, and spinach (DLI $=+3.24 \mathrm{~mol} \cdot \mathrm{m}^{-2} \cdot \mathrm{d}^{-1}$ for chard and kale, and $+1.44 \mathrm{~mol} \cdot \mathrm{m}^{-2} \cdot \mathrm{d}^{-1}$ for spinach as photoperiod differed). Increasing irradiance from 300 to $350 \mu \mathrm{mol} \cdot \mathrm{m}^{-2} \cdot \mathrm{s}^{-1}$ increased predicted spinach $P_{\mathrm{n}}$ by $15 \%$ and that of kale and chard by $9 \%$ to $11 \%$ (Table 4 ).

Responses to $\mathrm{CO}_{2}$. Kale and chard CSP was lower $(600-800 \mathrm{ppm})$ than that of spinach (1000-1200 ppm) (irradiance $=300$ $\mu \mathrm{mol} \cdot \mathrm{m}^{-2} \cdot \mathrm{s}^{-1}$; Fig. 1; Table 3). Responses observed on kale here were similar to those observed by others (700 ppm $\mathrm{CO}_{2}$ ) on $B$. olerace $a$ and $B$. napus under different irradiance levels (Bunce and Sicher, 2003; Dahal et al., 2012, respectively). Given all CSPs reported here are higher than the ambient $\mathrm{CO}_{2}$ levels, supplementing greenhouses or growth rooms with $\mathrm{CO}_{2}$ (above ambient) would likely increase the $P_{\mathrm{n}}$ of crops studied here (Table 3). In fact, injecting $\mathrm{CO}_{2}$ to increase $\mathrm{CO}_{2}$ levels to $800-1000 \mathrm{ppm}$ is commonplace in commercial vegetable production greenhouses to increase yield (personal observation; Dorais, 2003). For instance, increasing $\mathrm{CO}_{2}$ from 330 to $900 \mathrm{ppm}$ increased tomato yield by $21 \%$ (Dorais, 2003).

$P_{\mathrm{n}}$ in unventilated greenhouses or enclosed rooms can be limited by declining $\mathrm{CO}_{2}$ levels as plants use $\mathrm{CO}_{2}$ for photosynthesis. It is not uncommon for $\mathrm{CO}_{2}$ levels in a canopy to drop to $200-250 \mathrm{ppm}$ during the day in an unvented greenhouse or growth room (J. Erwin and J. Frantz, personal observations). Therefore, ventilating production environments with outdoor air (400 ppm $\mathrm{CO}_{2}$ ) will increase $\mathrm{CO}_{2}$ concentration inside thus increasing $P_{\mathrm{n}}$. Our data predict ventilating greenhouses to increase $\mathrm{CO}_{2}$ levels from 200 to $400 \mathrm{ppm}$ can result in a greater increase in $P_{\mathrm{n}}$ than that from increasing $\mathrm{CO}_{2}$ from 400 to $800 \mathrm{ppm}$ as would occur when using a $\mathrm{CO}_{2}$ injection system (Table 4). For instance, increasing $\mathrm{CO}_{2}$ from 200 to 400 ppm increased predicted $P_{\mathrm{n}}$ by $75 \%$ to $98 \%$ across species whereas increasing $\mathrm{CO}_{2}$ levels from $400 \mathrm{ppm}$ to the CSP increased predicted $P_{\mathrm{n}}$ by $38 \%$ to $68 \%$ across species (Table 4 ). These data emphasize the importance of ventilating to ensure canopy $\mathrm{CO}_{2}$ levels are at least similar to ambient outdoor levels. Of course, the predicted increases in $P_{\mathrm{n}}$ if $\mathrm{CO}_{2}$ is increased from 400 to $800 \mathrm{ppm}$ may be greater if irradiance was simultaneously increased to the LSP.

As with $P_{\mathrm{n}}$ responses to irradiance, although $\mathrm{CO}_{2}$ levels on the uppermost leaves may be at CSP levels, lower leaf $P_{\mathrm{n}}$ is likely not at CSP levels as $\mathrm{CO}_{2}$ is consumed by photosynthesis in the canopy and replaced slowly (depending on air circulation and ventilation). Therefore, increasing $\mathrm{CO}_{2}$ levels to above the CSP often results in increased yields as lower leaf $P_{\mathrm{n}}$ is less $\mathrm{CO}_{2}$ limited. This is increasingly important as leaf area index increases in a canopy. Kale and chard had lower CSP than spinach; therefore, these crops would perform better in greenhouses with poor ventilation or with close plant spacing than spinach (Table 3).

Respiration. Spinach, kale, and chard predicted $R_{\mathrm{d}}\left(24{ }^{\circ} \mathrm{C}\right)$ observed here are comparable with those measured by others although temperatures differed somewhat (Dahal et al., 2012; Yamori et al., 2005). We observed variation in $R_{\mathrm{d}}$ among species and among varieties of some species. Although spinach variety $R_{\mathrm{d}}$ was high and similar, kale and chard variety $R_{\mathrm{d}}$ varied with some varieties having a 4-fold higher $R_{\mathrm{d}}$ than with other varieties (Table 2). Variation in $R_{\mathrm{d}}$ among varieties of other vegetable species (such as asparagus) has also been observed (Kitazawa et al., 2011). Such variation in $R_{\mathrm{d}}$ among species and varieties here are especially important to quantify as $R_{\mathrm{d}}$ can be negatively correlated with postharvest performance (Kitazawa et al., 2011). For 
Table 4. Predicted instantaneous photosynthetic rates $\left(P_{\mathrm{n}}\right.$ per unit area; $\left.\mu \mathrm{mol} \mathrm{CO}_{2} \cdot \mathrm{m}^{-2} \cdot \mathrm{s}^{-1}\right)$ at low irradiance (typical cloudy day in winter; $\left.200 \mu \mathrm{mol} \cdot \mathrm{m}^{-2} \cdot \mathrm{s}^{-1}\right)$, ambient irradiance (typical $\left.300 \mu \mathrm{mol} \cdot \mathrm{m}^{-2} \cdot \mathrm{s}^{-1}\right)$, and at $95 \%$ of predicted $P_{\max }\left(P_{\mathrm{n}}\right.$ saturated) of kale (Brassica oleracea and B. napus pabularia), Swiss chard (Beta vulgaris), and spinach (Spinacea oleracea) varieties. Predicted $P_{\mathrm{n}}$ at low $\mathrm{CO}_{2}$ levels $\left(200\right.$ ppm; depleted enclosed environment), at ambient CO ${ }_{2}$ levels (400 ppm, current outdoor), and at $95 \%$ of predicted $P_{\max }$ of kale, Swiss chard, and spinach varieties. Percentage in parenthesis is the percent increase in $P_{\mathrm{n}}$ when increasing from the rate one line up and to the left, to the level above the number in parentheses. Letters denote mean separation [Tukey's HSD $(\alpha<0.05)]$ within a variety to increasing irradiance or increasing carbon dioxide concentration.

\begin{tabular}{|c|c|c|c|c|c|c|c|}
\hline \multirow[b]{2}{*}{ Species and cultivar } & \multicolumn{4}{|c|}{ Irradiance $\left(\mu \mathrm{mol} \cdot \mathrm{m}^{-2} \cdot \mathrm{s}^{-1}\right)$} & \multicolumn{3}{|c|}{ Carbon dioxide (ppm) } \\
\hline & Low 200 & Ambient 300 & +50350 & $P_{\mathrm{n}}$ Saturated $600-1,000$ & Deficient 200 & Ambient 400 & $P_{\mathrm{n}}$ Saturated $800-1,000$ \\
\hline \multicolumn{8}{|l|}{$\overline{\text { Kale }}$} \\
\hline 'Red Russian' & $9.46 \mathrm{~b}$ & $12.80 \mathrm{c}(+35 \%)$ & $14.13 \mathrm{~d}(+10 \%)$ & $22.34 \mathrm{f}(+75 \%)$ & $7.37 \mathrm{a}$ & $12.87 \mathrm{c}(+75 \%)$ & 17.81 e $(+38 \%)$ \\
\hline 'Toscano' & $8.96 \mathrm{~b}$ & $12.10 \mathrm{c}(+35 \%)$ & $13.34 \mathrm{~d}(+10 \%)$ & $21.04 \mathrm{e}(+74 \%)$ & $6.66 \mathrm{a}$ & $12.44 \mathrm{~cd}(+87 \%)$ & 18.98 e $(+53 \%)$ \\
\hline 'Winterbor' & $8.33 \mathrm{~b}$ & $10.90 \mathrm{c}(+31 \%)$ & $11.89 \mathrm{~d}(+9 \%)$ & $17.41 \mathrm{f}(+60 \%)$ & $4.42 \mathrm{a}$ & 8.77 b (+98\%) & 14.72 e $(+68 \%)$ \\
\hline \multicolumn{8}{|l|}{ Spinach } \\
\hline 'Melody' & $7.66 \mathrm{a}$ & $11.89 \mathrm{~b}(+55 \%)$ & $13.63 \mathrm{c}(+15 \%)$ & 26.58 e $(+124 \%)$ & $7.70 \mathrm{a}$ & $13.61 \mathrm{bc}(+77 \%)$ & $19.83 \mathrm{~d}(+46 \%)$ \\
\hline 'Harmony' & $6.37 \mathrm{a}$ & $10.22 \mathrm{~b}(+60 \%)$ & $11.78 \mathrm{c}(+15 \%)$ & $22.45 \mathrm{~d}(+120 \%)$ & $7.24 \mathrm{a}$ & $13.04 \mathrm{c}(+80 \%)$ & $19.59 \mathrm{~d}(+50 \%)$ \\
\hline 'Bloomsdale LS' & $6.27 \mathrm{a}$ & $9.85 \mathrm{~b}(+57 \%)$ & $11.31 \mathrm{c}(+15 \%)$ & 22.27 e $(+126 \%)$ & $6.94 \mathrm{a}$ & $12.84 \mathrm{c}(+85 \%)$ & $20.00 \mathrm{~d}(+56 \%)$ \\
\hline \multicolumn{8}{|l|}{ Chard } \\
\hline 'Yellow' & $8.21 \mathrm{~b}$ & $10.81 \mathrm{c}(+32 \%)$ & $11.77 \mathrm{~d}(+9 \%)$ & 16.35 e $(+53 \%)$ & $5.70 \mathrm{a}$ & $10.75 \mathrm{c}(+88 \%)$ & 16.89 e $(+63 \%)$ \\
\hline 'Rhubarb' & $7.55 \mathrm{a}$ & $10.52 \mathrm{~b}(+39 \%)$ & $11.67 \mathrm{c}(+11 \%)$ & 17.87 e $(+70 \%)$ & $6.23 \mathrm{a}$ & $11.33 \mathrm{bc}(+82 \%)$ & $16.55 \mathrm{~d}(+46 \%)$ \\
\hline 'Fordhook Giant' & $9.05 \mathrm{~b}$ & $12.37 \mathrm{c}(+37 \%)$ & $13.69 \mathrm{~d}(+11 \%)$ & $21.86 \mathrm{f}(+77 \%)$ & $5.76 \mathrm{a}$ & $10.87 \mathrm{c}(+89 \%)$ & 17.50 e $(+61 \%)$ \\
\hline 'Bright Lights' & $8.54 \mathrm{~b}$ & $11.12 \mathrm{~cd}(+30 \%)$ & $12.08 \mathrm{~d}(+9 \%)$ & $16.62 \mathrm{fe}(+50 \%)$ & $5.53 \mathrm{a}$ & $10.92 \mathrm{c}(+97 \%)$ & $19.17 \mathrm{f}(+76 \%)$ \\
\hline
\end{tabular}

HSD $=$ honestly significant difference.

instance, data here suggest that spinach may have a shorter postharvest life than kale and that among kale varieties and among chard varieties, 'Bright Lights' may have a shorter postharvest life than 'Rhubarb' (Table 2).

Irradiance versus $\mathrm{CO}_{2}$. The question arises as to whether a spinach, kale, or chard producer should increase irradiance or $\mathrm{CO}_{2}$ to increase yield most. Low $\mathrm{CO}_{2}$ conditions $(200 \mathrm{ppm})$ reduced predicted $P_{\mathrm{n}}$ more than low irradiance $\left(200 \mu \mathrm{mol} \cdot \mathrm{m}^{-2} \cdot \mathrm{s}^{-1}\right)$ conditions on both kale and chard here (Table 4). Therefore, ventilating enclosed production spaces (where $\mathrm{CO}_{2}$ may have dropped to $200 \mathrm{ppm}$ ) to ensure $\mathrm{CO}_{2}$ levels are at ambient levels (400 ppm) may increase $P_{\mathrm{n}}$ and likely yield on kale and chard more than on spinach. In contrast, in nearly all cases (except 'Toscano' kale, and 'Yellow' and 'Bright Lights' chard), increasing irradiance from ambient irradiance $\left(300 \mu \mathrm{mol} \cdot \mathrm{m}^{-2} \cdot \mathrm{s}^{-1}\right)$ to the LSP increased predicted $P_{\mathrm{n}}$ more than increasing $\mathrm{CO}_{2}$ from ambient $(400 \mathrm{ppm})$ to the CSP (Table 4). This suggests that irradiance may be more limiting than $\mathrm{CO}_{2}$ with the crops studied here.

Future work must examine the synergy between irradiance and $\mathrm{CO}_{2}$ on kale, chard, and spinach. Increasing $\mathrm{CO}_{2}$ from 400 to 800 ppm and increasing irradiance from 400 to $800 \mu \mathrm{mol} \cdot \mathrm{m}^{-2} \cdot \mathrm{s}^{-1}$ significantly increased lettuce dry weight by $25 \%$ (1.5 g/plant) and $19 \%,(1.15 \mathrm{~g} /$ plant), respectively (Chagvardieff et al., 1994). However, increasing $\mathrm{CO}_{2}$ concentration and irradiance simultaneously acted synergistically $[2.65 \mathrm{~g} /$ plant when benefits added individually vs. $4.21 \mathrm{~g} / \mathrm{plant}(+69 \%)$ when increased together] when conducted 23 to $40 \mathrm{~d}$ after sowing (Chagvardieff et al., 1994).

Variety differences. Varieties (of some species) differed in response to increasing irradiance or $\mathrm{CO}_{2}$ suggesting different genetic backgrounds. There was little variation among spinach varieties in $P_{\max }, \mathrm{LCP}, \mathrm{CCP}$, LSP, and CSP (Tables 1 and 2). However, there were substantial differences among kale and chard varieties for these same parameters (Tables 1 and 2). This was not unexpected as vegetable crops are often interspecific hybrids, and varieties can vary greatly genetically. Similar variation in $P_{\max }$ among lettuce varieties was observed by Behr and Wiebe (1992). Gu et al. (2012) observed variation in $P_{\max }(17 \%$ to $25 \%$ variation) in rice (13 lines; Oryza sativa L.) at ambient $\mathrm{CO}_{2}$ levels $(380 \mathrm{ppm})$ and that variation was associated with stomatal and mesophyll conductance. Yu et al. (2016) found variation in Cucumis $P_{\mathrm{n}}$ varieties to changes in irradiance was associated with differences in leaf cholorophyll content. In another work, differences in Arabidopsis variety $P_{\mathrm{n}}$ responses to changing irradiance was associated with differences in Rubsico activation and $g_{S}$ (Kaiser et al., 2016). Whatever the basis, our data infer genetic diversity (based on $P_{\mathrm{n}}$ responses) of kale and chard may be greater than that of the spinach varieties studied here.

Combining both $P_{n}$ and $R_{d}$. It cannot also be assumed that higher $P_{\mathrm{n}}$ will result in increased fresh or dry weight and yield as yield is associated with carbon loss or $R_{\mathrm{d}}$. As $R_{\mathrm{d}}$ occurs during both day and night, it can have a significant negative impact on net daily carbon gain. When predicted daily carbon gain was calculated by taking both $P_{\mathrm{n}}$ (Rd already quantified in direct $P_{\mathrm{n}}$ readings) and $R_{\mathrm{d}}$ (at night only) into account net carbon gain $=\left[\left(P_{\max } \times 18 \mathrm{~h} \cdot \mathrm{d}^{-1}(\right.\right.$ kale $)$ or $8 \mathrm{~h} \cdot \mathrm{d}^{-1}($ spinach $\left.)\right]-\left[\left(R_{\mathrm{d}} \times 8 \mathrm{~h} \cdot \mathrm{d}^{-1}(\right.\right.$ kale $)$ or $16 \mathrm{~h} \cdot \mathrm{d}^{-1}$ (spinach) $\}$, we observed spinach carbon gain $/ \mathrm{d}(380.8-80.0=300.8 \mu \mathrm{mol}$ $\left.\mathrm{CO}_{2} \cdot \mathrm{m}^{-2} \cdot \mathrm{s}^{-1}\right)$ was lower than that of kale $\left(365.4-6.6=358.8 \mu \mathrm{mol} \mathrm{CO} \mathrm{CO}^{-2} \cdot \mathrm{s}^{-1}\right)$ even though $P_{\max }$ was greater (Table 2 ).

Take home messages.

1. Kale and chard $P_{\mathrm{n}}$ saturated at lower (600-800 $\left.\mu \mathrm{mol} \cdot \mathrm{m}^{-2} \cdot \mathrm{s}^{-1}\right) \quad$ irradiance levels than spinach $P_{\mathrm{n}}$ (1000-1200 $\left.\mu \mathrm{mol} \cdot \mathrm{m}^{-2} \cdot \mathrm{s}^{-1}\right)$, and kale and chard may be better suited for production in low-irradiance facilities than spinach. Also, as spinach had a higher LCP $\left(60-75 \mu \mathrm{mol} \cdot \mathrm{m}^{-2} \cdot \mathrm{s}^{-1}\right)$ than kale $(10-$ $\left.15 \mu \mathrm{mol} \cdot \mathrm{m}^{-2} \cdot \mathrm{s}^{-1}\right)$, kale may be grown under lower irradiance conditions than spinach and still have an increase in mass.

2. Kale and chard CSP were lower (600-800 ppm) than that of spinach (1000-1200 ppm). Given all CSPs reported here are higher than ambient $\mathrm{CO}_{2}$ levels, supplementing $\mathrm{CO}_{2}$ would increase the $P_{\mathrm{n}}$ of crops studied here.

3. Ventilating greenhouses to increase $\mathrm{CO}_{2}$ from 200 to $400 \mathrm{ppm}$ may result in a greater increase in $P_{\mathrm{n}}$ than that from increasing $\mathrm{CO}_{2}$ from 400 to $800 \mathrm{ppm}$.

4. Although spinach variety $R_{\mathrm{d}}$ was similar, kale and chard variety $R_{\mathrm{d}}$ varied with some varieties having a 4-fold higher $R_{\mathrm{d}}$ than others.

5. Low $\mathrm{CO}_{2}$ reduced kale and chard $P_{\mathrm{n}}$ more than low irradiance. Therefore, ventilating production spaces to ensure $\mathrm{CO}_{2}$ levels are at $400 \mathrm{ppm}$ may increase yield more on kale and chard than on spinach.

6. In nearly all cases (except 'Toscano' kale, and 'Yellow' and 'Bright Lights' chard), increasing irradiance from 300 $\mu \mathrm{mol} \cdot \mathrm{m}^{-2} \cdot \mathrm{s}^{-1}$ to the LSP increased the $P_{\mathrm{n}}$ more than increasing $\mathrm{CO}_{2}$ from ambient to the CSP. This suggests irradiance may be more limiting than $\mathrm{CO}_{2}$ on these crops.

7. When predicted daily carbon gain was calculated by taking both $P_{\mathrm{n}}$ and $R_{\mathrm{d}}$ into account, spinach carbon gain per day was lower than that of kale even though the $P_{\max }$ was greater.

\section{Literature Cited}

Aleric, K.M. and K.L. Kirkman. 2005. Growth and photosynthetic responses of the federally endangered shrub, Lindera melissifolia (Lauraceae), to varied light environments. Amer. J. Bot. 92:682-689. 
Austin, R.B. 1989. Genetic variation in photosynthesis. J. Agr. Sci. Camb. 112:287-294.

Behr, U. and H.J. Wiebe. 1992. Relations between photosynthesis and nitrate content of lettuce cultivars. Sci. Hort. 49:175-179.

Bertoia, M.L., K.J. Mukamal, L.E. Cahill, T. Hou, D.S. Ludwig, D. Mozaffarian, W.C. Willett, F.B. Boese, and N.P.A. Huner. 1990. Effect of growth temperature and temperature shifts on spinach leaf morphology and photosynthesis. Plant Physiol. 94:1830-1836.

Bertoia, M.L., K.J. Mukamal, L.E. Cahill, T. Hou, D.S. Ludwig, D. Mozaffarian, W.C. Willett, F.B. Hu, and E.B. Rimm. 2015. Changes in intake of fruits and vegetables and weight change in United States men and women followed for up to 24 years: Analysis from three prospective cohort studies. PLOS Medicine, doi: 10.1371/ journal.pmed.1001878.

Björkman, O. 1981. Responses of different quantum flux densities, p. 57-107. In: O.L. Lange, P.S. Nobel, C.B. Osmond, and H. Ziegler (eds.). Encyclopedia of plant physiology. vol. 12A, Springer-Verlag, Berlin, Germany.

Boese, S.R. and N.P.A. Huner. 1990. Effect of growth temperature and temperature shifts on spinach leaf morphology and photosynthesis. Plant Physiol. 94:1830-1836.

Bunce, J.A. and R.C. Sicher. 2003. Daily irradiance and feedback inhibition of photosynthesis at elevated carbon dioxide concentration in Brassica oleracea. Photosynthetica 41(4):481-488.

Bunce, J.A. and L.H. Ziska. 2000. Impact of measurement irradiance on acclimation of photosynthesis to elevated $\mathrm{CO} 2$ concentration in several plant species. Photosynthetica 37(4): 509-517.

Chagvardieff, P., T. d'Aletto, and M. André. 1994. Specific effects of irradiance and $\mathrm{CO} 2$ concentration doublings on productivity and mineral content in lettuce. Adv. Space Res. 14(11): 269-275.

Colonna, E., Y. Rouphaei, G. Barbieri, and S. De Pascale. 2016. Nutritional quality of ten leafy vegetables harvested at two light intensities. Food Chem. 199:702-710.

Dahal, K., K. Kane, W. Gadapati, E. Webb, L.V. Savitch, J. Singh, P. Sharma, F. Sarhan, F.J. Longstaffe, B. Grodzinski, and N.P.A. Hüner. 2012. The effects of phenotypic plasticity on photosynthetic performance in winter rye, winter wheat and Brassica napus. Physiol. Plant. 144(2):169-188.

Dorais, M. 2003. The use of supplemental lighting for vegetable crop production: Light intensity, crop response, nutrition, crop management, cultural practices. Can. Greenhouse Conf. 2003, 1-8.

Farquhar, G.D., S. von Caemmerer, and J.A. Berry. 1980. A biochemical model of $\mathrm{CO}_{2}$ assimilation in leaves of $\mathrm{C}_{3}$ species. Planta 149:78-90.

Feldmann, C. and U. Hamm. 2015. Consumers' perceptions and preferences for local food: A review. Food Qual. Prefer. 40:152-164.

Fu, Y., H. Li, J. Yu, H. Liu, Z. Cao, N.S. Manukovsky, and H. Liu. 2017. Interaction effects of light intensity and nitrogen concentration on growth, photosynthetic characteristics and quality of lettuce (Lactuca sativa L. var. youmaicai). Sci. Hort. 214(5):51-57.

Gaudreau, L., J. Charbonneau, L.P. Vezina, and A. Gosselin. 1994. Photoperiod and PPF influence growth and quality of greenhouse-grown lettuce. HortScience 29:1285-1289.

Gent, M.P.N. 2016. Effect of irradiance and temperature on composition of spinach. HortScience 51:133-140.

Goudrian, J. 1979. A family of saturation type curves, especially in relation to photosynthesis. Ann. Bot. 43:783-785.

Gu, J., X. Yin, T. Stomph, H. Wang, and P.C. Struik. 2012. Physiological basis of genetic variation in leaf photosynthesis among rice (Oryza sativa L.) introgression lines under drought and well-watered conditions. J. Expt. Bot. 63(14):5137-5153.

Heuvelink, E. and M. Dorais. 2003. Crop growth and yield. In: E. Heuvelink (ed.). Tomato. CAB International, Wallingford, Oxon, UK.

Hu, E. and B. Rimm. 2015. Changes in intake of fruits and vegetables and weight change in United States men and women followed for up to 24 years: Analysis from three prospective cohort studies. PLOS Medicine 12:e1001878.

Johnson, I.R., J. Thornley, J.M. Frantz, and B. Bugbee. 2010. A model of canopy photosynthesis incorporating protein distribution through the canopy and its acclimation to light, temperature and $\mathrm{CO}_{2}$. Ann. Bot. 106:735-749.

Kaiser, E., A. Morales, J. Harbinson, J. Kromdijk, E. Heuvelink, and L.F.M. Marcelis. 2015. Dynamic photosynthesis in different environmental conditions. J. Expt. Bot. 66(9):2415-2426.

Kaiser, E., A. Morales, J. Harbinson, E. Heuvelink, A.E. Prinzenberg, and L.F.M. Marcelis. 2016. Metabolic and diffusional limitations of photosynthesis in fluctuating irradiance in Arabidopsis thaliana. Sci. Rep. 6:31252.

Kitazawa, H., S. Motoki, T. Maeda, Y. Ishikawa, Y. Hamauzu, K. Matsushima, H. Sakai, T. Shiina, and Y. Kyutoku. 2011. Effects of storage temperature on the postharvest quality of three asparagus cultivars harvested in spring. J. Jpn. Soc. Hort. Sci. 80(1):76-81.

Kretchen, D.W. and F.S. Howlett. 1970. CO2 enrichment for vegetable production. Transactions of the ASAE13:252-256.

Laitat, E. and H. Boussard. 1995. Comparative response on gas exchange of Picea spp. exposed to increased atmospheric $\mathrm{CO}_{2}$ in open top chambers at two test sites, p. 241-248. Journal of Biogeography, Vol. 22, No. 2/3, Terrestrial Ecosystem Interactions with Global Change, Volume 1 (March-May 1995).

Lambers, H., F.S. Chapin, III, and T.L. Pons. 2008. Photosynthesis, p. 11-99. Plant Physiological ecology. Springer, New York, NY.

Marino, G., M. Aqil, and B. Shipley. 2010. The leaf economics spectrum and the prediction of photosynthetic light-response curves. Funct. Ecol. 24:263-272.

Peek, M.S., E. Russek-Cohen, D.A. Wait, and I.N. Forseth. 2002. Physiological response curve analysis using nonlinear mixed models. Oecologia 132:175-180.

Pons, T.L. 2012. Interaction of temperature and irradiance effects on photosynthetic acclimation in two accessions of Arabidopsis thaliana. Photosynth. Res. 113:207-219.

Potvin, C., M.J. Lechowicz, and S. Tardif. 1990. The statistical analysis of eco- physiological response curves obtained from experiments involving repeated measures. Ecology 71 : 1389-1400.

Ruhil, K., Sheeba, A. Ahmad, M. Iqbal, and B.C. Tripathy. 2015. Photosynthesis and growth responses of mustard (Brassica juncea L. cv Pusa Bold) plants to free air carbon dioxide enrichment. Protoplasma 252:935-946.

Samuoliene, G., A. Brazaityte, J. Jankauskiene, A. Virsile, R. Sirtautas, A. Novickovas, S Sakalauskaite, and P. Duchovskis. 2013. LED irradiance level affects growth and nutritional quality of Brassica microgreens. Cent. Eur. J. Biol. 8:1241-1249.

Yamori, W., K. Noguchi, and I. Terashima. 2005. Temperature acclimation of photosynthesis in spinach leaves: Analysis of photosynthetic components and temperature dependencies of photosynthetic partial reactions. Plant Cell Environ. 28:536-547.

Yu, X., R. Zhou, X. Wang, K.H. Kjaer, E. Rosenqvist, C. Ottosen, and J. Chen. 2016. Evaluation of genotypic variation during leaf development in four Cucumis genotypes and their response to high light conditions. Environ. Expt. Bot. 124:100-109. 